\title{
AN EVALUATION OF ABUSE AND NEGLECT IN ELDERLY WITH THE HWALEK-SENGSTOCK ELDER ABUSE SCREENING TEST
}

Turkish Journal of Geriatrics

DOI: 10.31086/tjgeri.2018137961

2018;21 (1):16-24

- Hande ŞAHIN

- Sibel ERKAL ${ }^{2}$
CORRESPONDANCE

Hande ŞAHIN

Kırıkkale University, Faculty of Health Sciences Department of Social Work

Kırıkkale, Turkey

Phone: 3183573738

e-mail: hande_k1979@yahoo.com

Received: 22/02/2017

Accepted: 18/12/2017

Kırıkkale University, Faculty of Health Sciences, Department of Social Work Hacettepe University, Faculty of Economics and Administrative Sciences, Department of Family and Consumer Sciences

\section{Abstract}

Introduction: The participants in this study, which was conducted to evaluate abuse and neglect in the elderly using the Hwalek-Sengstock Elder Abuse Screening Test, comprised older adults aged 65 and over, residing in Etimesgut, Ankara.

Materials and Method:The study employed the Hwalek-Sengstock Elder Abuse Screening Test as the data collection instrument. In addition to standard deviation and arithmetic mean, the t-test was used for data comparisons between two groups, and analysis of variance was conducted when analyzing more than two groups.

Results: The abuse and neglect status of the participants displayed significant differences with respect to educational attainment, monthly income, number of children, other household members, ownership of residence, and social security $(p<0.05)$

Conclusion: The elderly experience serious health problems because of physical, psychological, sexual, and economic violence and neglect.

Keywords: Aged; Elder abuse; Surveys and Questionnaires/standards

\section{ARASTIRMA}

\section{YAŞLILARIN ISTISMAR VE IHMALE UĞRAMA DURUMLARININ HWALEK-SENGSTOCK YASSLI ISTISMARI TARAMA TESTI ILE DEĞERLENDIRILMESi}

\section{$\ddot{O}_{z}$}

Giriş: Yaşılıarın istismar ve inmale uğrama durumlarının Hwalek-Sengstock Yaşlı İstismarı Tarama Testi ile değerlendirilmesini amaçlayan bu çalışmaya Ankara ili, Etimesgut ilçesinde ikamet eden 65 yaş ve üzeri yaşlılar katılmıştır.

Gereç ve Yöntem: Çalışmada veri toplama aracı olarak "Hwalek-Sengstock Yaşlı İstismarı Tarama Testi" kullanılmıştır. Verilerin çözümlenmesinde standart sapma, aritmetik ortalama, ikili gruplar için t testi, ikiden daha fazla grup için ise varyans analizi kullanılmıştır.

Bulgular: Yaşılıarın istismar ve ihmale uğrama durumlarının öğretim düzeyine, aylık gelire, çocuk sayısına, birlikte yaşanılan kişiye, yaşadığı evin mülkiyet durumuna ve sosyal güvencesine göre anlamlı bir farklııı gösterdiği $(p<0.05)$ belirlenmiştir.

Sonuç: Yaşlılar yaşadıkları fiziksel, psikolojik, cinsel, ekonomik şiddetten ve ihmalden dolayı ciddi sağlık sorunları yaşamaktadır.

Anahtar sözcükler: Yaşlı; Yaşlı istismarı; Değerlendirme 


\section{INTRODUCTION}

The proportion of elderly persons within the global population is rapidly increasing with decreasing natality, improving living standards, and the consequent increasing human longevity (1). According to the United Nations World Population Prospects Report published in 2010, the 69.31year life expectancy at that time was expected to reach 75.5 years by 2050. In Turkey, the 78-year life expectancy in 2014 is anticipated to reach 78.5 years by $2050(2,3)$. The number of elderly victims of abuse and neglect is expected to rise in line with the increase in the elderly population (4).

The increasing population, physical and sociocultural changes in old age, and deteriorating economic conditions lead to inadequate home or institutional care support for older adults, and elder abuse and neglect (5). According to the International Network for the Prevention of Elder Abuse and the World Health Organization Toronto Declaration, elder abuse is "a single or repeated act, or lack of appropriate action, occurring within any relationship where there is an expectation of trust which causes harm or distress to an older person," while neglect is an intentional or unintentional failure to meet the social, physical, or emotional needs of an older adult $(4,6)$. It can take many forms, including physical, emotional, financial, and sexual abuse, as well as self-neglect- where there is no perpetrator (7). The United Nations International Plan of Action (2002) adopted in Madrid recognized the importance of addressing abuse and neglect of older adults and incorporated it within its framework for universal human rights (8).

The current evidence, as reported by the $\mathrm{WHO}$ European Report 2011, shows an estimated 2500 annual homicides among older people, as a result of maltreatment committed by family members. In addition, the document estimated that about 29 million of the European subjects analyzed (19.4\% of the total) are victims of psychological abuse, 6 million of financial abuse, 4 million of physical mistreatment and 1 million of sexual mistreatment (9).
Several studies on elder abuse and neglect have been conducted both in Turkey and abroad (10-15). These studies show that elder abuse is often perpetrated by the relatives and caregivers of the older person, and that emotional abuse is the most frequently committed form. The present study was planned and conducted to evaluate abuse and neglect in older adults using the Hwalek-Sengstock Elder Abuse Screening Test.

\section{MATERIALS AND METHOD}

The participants in this study, which aimed at evaluating elder abuse and neglect using the Hwalek-Sengstock Elder Abuse Screening Test, comprised older adults aged $\geq 65$, residing in Etimesgut, Ankara. The study employed systematic sampling, a probability sampling method, because of time and cost restrictions. The sample group comprised 508 older adults.

Sample size calculation was performed to estimate the overall score of Hwalek-Sengstock test. In the research sample size was calculated using the formula ( $n=N . s 2 . Z \cdot 2 /((N-1) \cdot d 2+s 2 . Z \cdot 2)$ that is recommended for quantitative studies and finite population (16). From the parameters that form the formula; standard deviation calculated was $s=0.22$, the effect size was $d=0.02$, the significance level was $\alpha=0.05=Z \alpha=1.96$ and the minimum sample was calculated with this formula was 465 people. Considering missing and not returning questionnaires, a total of 550 questionnaires were distributed and 508 questionnaires were evaluated. In the study aiming to determine the level of abuse in the elderly, the overall mean value of the effect size and s values for the abuse variables 1 and 2 was taken into account.

Questionnaires were used as the data collection method. The study made use of the HwalekSengstock Elder Abuse Screening Test developed by Hwalek and Sengstock and adapted to Turkish by Özmete $(4,17)$. 


\section{Hwalek-Sengstock Elder Abuse Screening}

Test: The scale consists of 15 items and three conceptual categories (factors). These three factors are "overt violation of personal rights and direct abuse" (items 4, 9, 10, 11, and 15), "characteristics of the elder that make him or her vulnerable to abuse" (items 1, 3, and 6) and "characteristics of potentially abusive situations" (items $2,5,7,8,12$, 13 , and 14) (4). In the study, responses to each item in the measure were coded as 1 for experiencing abuse and neglect and 2 for not experienced. In this case, the average scores ranged from 1 to 2 , and approaching 1 indicates that the level of abuse and neglect of the elderly increases. Items 1, 2, 4, 6, 12 and 14 in the test are reverse-coded.

In the study, it was found that the obtained parametric test assumptions were met. normality assumtion was checked by Kolmogorov-Smirnov test, skewness and curtosis coefficient.

Each item in the Hwalek-Sengstock Elder Abuse Screening Test was represented as percentage distribution, arithmetic mean, and standard deviation. In comparing participants' demographic characteristics with the scale items, the t-test was used when analyzing two groups and an analysis of variance was conducted for more than two groups (for the given parametric test assumptions obtained). As a result of the variance analysis, the source of the difference was determined by the Tukey test. Additionally, reliability was assessed with Cronbach's Alpha coefficient, which was computed as 0.745 .

\section{Ethical consideration}

Signed informed consent was obtained from all elderly. The ethics committee of university approved the study, which was conducted according to the Declaration of Helsinki.

\section{RESULTS}

The study data revealed that $29.9 \%$ of the older adults were female and $82.1 \%$ were male, while $82.1 \%$ of the participants were 75 years old and under. Of the total, $50.4 \%$ were elementary school graduates, $78 \%$ had a monthly income of $2250 \mathrm{TL}$ and under, $91 \%$ had two or more children, and 53\% lived with their spouses. Homeowners accounted for $85.8 \%$ of the participants. The percentages of participants who were socially insured by SSK (for private and public sector workers), Emekli Sandığı (for civil servants), and Bağ-kur (for artisans, farmers, and the self-employed) were $51 \%, 28 \%$, and $15.2 \%$, respectively (Table 1 ).

Descriptive statistics for the Hwalek-Sengstock Elder Abuse Screening Test are presented in Table 2. An overall majority of the older adults replied "Yes" to "Do you have anyone who spends time with you, taking you shopping or to the doctor?" "Are you helping to support someone?" and replied "No" to "Who makes decisions about your life?" the overall majority replied "I." Subscale and scale scores are overall scores with a maximum of 2 .

Descriptive statistics for the subscales (factors) of the Hwalek-Sengstock Elder Abuse Screening Test are presented in Table 3. In general, the level of neglect and abuse was low for all three subscales. The highest subscale means were computed for "Characteristics of potentially abusive situations" $(\bar{X}=1.810)$. And the lowest subscale means were computed for "Characteristics of the elder that make him or her vulnerable to abuse" ( $\bar{X}=1.778)$.

The t-test and analysis of variance results are presented in Table 4. No significant differences in neglect and abuse status of the participants were observed with respect to gender or age $(p>0.05)$, while there were significant differences with respect to educational attainment, monthly income, number of children, other household members, ownership of residence, and social security $(p<0.05)$. The groups with increased exposure to neglect and abuse than the other groups were those who had an elementary school degree or less, who had a monthly income of 1000TL and under, who were childless, who lived alone, who were tenants, who had no social security, and who had a green card. 
Table 1. Distribution of participants according to their individual characteristics $(n=508)$.

\begin{tabular}{|c|c|c|c|}
\hline Variables & Group & $\mathbf{n}$ & $\%$ \\
\hline \multirow{2}{*}{ Gender } & Female & 152 & 29.9 \\
\hline & Male & 356 & 70.1 \\
\hline \multirow{5}{*}{ Age } & $65-70$ & 278 & 54.7 \\
\hline & $71-75$ & 139 & 27.4 \\
\hline & $76-80$ & 62 & 12.2 \\
\hline & $81-85$ & 19 & 3.7 \\
\hline & $\geq 85$ & 10 & 2.0 \\
\hline \multirow{4}{*}{ Education Level } & Elementary school or less & 256 & 50.4 \\
\hline & Middle School & 100 & 19.7 \\
\hline & High School & 92 & 18.1 \\
\hline & University & 60 & 11.8 \\
\hline \multirow{5}{*}{ Monthly Income } & $\leq 1000 \mathrm{TL}$ & 68 & 13.4 \\
\hline & $1001-1500$ & 188 & 37.0 \\
\hline & $1501-2250$ & 140 & 27.6 \\
\hline & 2251-3000 & 63 & 12.4 \\
\hline & 3001 and over & 49 & 9.6 \\
\hline Number of Children & $\begin{array}{r}\text { None } \\
1 \\
2 \\
3 \\
4 \\
5 \text { or more }\end{array}$ & $\begin{array}{r}16 \\
30 \\
128 \\
150 \\
109 \\
75\end{array}$ & $\begin{array}{r}3.1 \\
5.9 \\
25.2 \\
29.5 \\
21.5 \\
14.8\end{array}$ \\
\hline Other Household Members & $\begin{array}{r}\text { Alone } \\
\text { With spouse } \\
\text { With relative } \\
\text { With spouse and children } \\
\text { Other }\end{array}$ & $\begin{array}{r}83 \\
269 \\
14 \\
117 \\
25 \\
\end{array}$ & $\begin{array}{r}16.3 \\
53.0 \\
2.8 \\
23.0 \\
4.9 \\
\end{array}$ \\
\hline Ownership of Residence & $\begin{array}{r}\text { Home owner } \\
\text { Tenant }\end{array}$ & $\begin{array}{r}436 \\
72 \\
\end{array}$ & $\begin{array}{l}85.8 \\
14.2 \\
\end{array}$ \\
\hline Social Security & $\begin{array}{r}\text { None } \\
\text { Green Card } \\
\text { Emekli Sandığı } \\
\text { Bağ-kur } \\
\text { SSK }\end{array}$ & $\begin{array}{r}7 \\
23 \\
142 \\
77 \\
259 \\
\end{array}$ & $\begin{array}{r}1.4 \\
4.5 \\
28.0 \\
15.2 \\
51.0\end{array}$ \\
\hline Total & & 508 & 100.0 \\
\hline
\end{tabular}


Table 2. Descriptive statistics for the Hwalek-Sengstock Elder Abuse Screening Test.

\begin{tabular}{|c|c|c|c|c|}
\hline \multirow{2}{*}{ Items } & \multicolumn{3}{|c|}{ Yes } & \multirow{2}{*}{ No } \\
\hline & $f$ & $\%$ & $f$ & \\
\hline $\begin{array}{l}\text { 1. Do you have anyone who spends time with you, taking you } \\
\text { shopping or to the doctor? }\end{array}$ & 372 & 73.2 & 136 & 26.8 \\
\hline 2. Are you helping to support someone? & 305 & 60.0 & 203 & 40.0 \\
\hline 3. Are you sad or lonely often? & 126 & 24.8 & 382 & 75.2 \\
\hline \multirow{2}{*}{$\begin{array}{l}\text { 4. Who makes decisions about your life- like how you should live or } \\
\text { where you should live? }\end{array}$} & \multicolumn{2}{|c|}{ Myself } & \multicolumn{2}{|c|}{ Someone else } \\
\hline & 445 & 87.6 & 63 & 12.4 \\
\hline 5. Do you feel uncomfortable with anyone in your family? & 52 & 10.4 & 455 & 89.6 \\
\hline 6. Can you take your own medication and get around by yourself? & 432 & 85.0 & 76 & 15.0 \\
\hline 7. Do you feel that nobody wants you around? & 79 & 15.6 & 429 & 84.4 \\
\hline 8. Does anyone in your family drink a lot? & 67 & 13.2 & 441 & 86.8 \\
\hline $\begin{array}{l}\text { 9. Does someone in your family make you stay in bed or tell you } \\
\text { you're sick when you know you're not? }\end{array}$ & 73 & 14.4 & 435 & 85.6 \\
\hline 10. Has anyone forced you to do things you did not want to do? & 41 & 8.1 & 467 & 91.9 \\
\hline 11. Has anyone taken things that belong to you without your consent? & 59 & 11.6 & 449 & 88.4 \\
\hline 12. Do you trust most of the people in your family? & 440 & 86.6 & 68 & 13.4 \\
\hline 13. Does anyone tell you that you give them too much trouble? & 55 & 10.8 & 453 & 89.2 \\
\hline 14. Do you have enough privacy at home? & 462 & 90.9 & 46 & 9.1 \\
\hline 15. Has anyone close to you tried to hurt you or harm you recently? & 45 & 8.9 & 463 & 91.1 \\
\hline
\end{tabular}

Table 3. Descriptive statistics for the subscales of the Hwalek-Sengstock Elder Abuse Screening Test.

\begin{tabular}{|c|c|c|c|c|}
\hline Subscales / Factors & $\mathbf{n}$ & $\begin{array}{r}\text { Number of } \\
\text { Items }\end{array}$ & $\bar{x}$ & sd \\
\hline Overt violation of personal rights and direct abuse & 508 & 5 & 1.789 & 0.172 \\
\hline $\begin{array}{l}\text { Characteristics of the elder that make him or her vulnerable to } \\
\text { abuse }\end{array}$ & 508 & 3 & 1.778 & 0.259 \\
\hline Characteristics of potentially abusive situations & 508 & 7 & 1.810 & 0.233 \\
\hline Overall & 508 & 15 & 1.796 & 0.148 \\
\hline
\end{tabular}


Table 4. Distribution of the Hwalek-Sengstock Elder Abuse Screening Test by the demographic characteristics of the participants $(n=508)$.

\begin{tabular}{|c|c|c|c|c|c|}
\hline Variable & Group & $\bar{X}$ & sd & $t / F$ & $\mathbf{P}$ \\
\hline \multirow{2}{*}{ Gender } & Female & 1.81 & 0.11 & \multirow{2}{*}{1.772} & \multirow{2}{*}{0.077} \\
\hline & Male & 1.78 & 0.14 & & \\
\hline \multirow{5}{*}{ Age } & $65-70$ & 1.79 & 0.14 & \multirow{5}{*}{0.880} & \multirow{5}{*}{0.476} \\
\hline & $71-75$ & 1.80 & 0.12 & & \\
\hline & $76-80$ & 1.80 & 0.12 & & \\
\hline & $81-85$ & 1.82 & 0.07 & & \\
\hline & $\geq 85$ & 1.74 & 0.19 & & \\
\hline \multirow{4}{*}{ Education } & Elementary school or less & $1.77 a$ & 0.13 & \multirow{4}{*}{2.703} & \multirow{4}{*}{0.045} \\
\hline & Middle School & $1.80 b$ & 0.13 & & \\
\hline & High School & $1.81 b$ & 0.12 & & \\
\hline & University & $1.82 b$ & 0.13 & & \\
\hline \multirow{5}{*}{ Monthly Income } & $\leq 1000 \mathrm{TL}$ & $1.73 a$ & 0.16 & \multirow{5}{*}{5.346} & \multirow{5}{*}{$p<0.001 * *$} \\
\hline & 1001-1500 & $1.79 b$ & 0.13 & & \\
\hline & $1501-2250$ & $1.80 \mathrm{~b}$ & 0.13 & & \\
\hline & $2251-3000$ & $1.82 b$ & 0.10 & & \\
\hline & 3001 and over & $1.83 b$ & 0.12 & & \\
\hline \multirow{6}{*}{$\begin{array}{l}\text { Number of } \\
\text { Children }\end{array}$} & & $1.67 a$ & 0.21 & \multirow{6}{*}{4.540} & \multirow{6}{*}{$p<0.001^{* *}$} \\
\hline & None & $1.77 b$ & 0.16 & & \\
\hline & & $1.81 b$ & 0.11 & & \\
\hline & 3 & $1.81 b$ & 0.12 & & \\
\hline & $\begin{array}{l}4 \\
5 \text { or more }\end{array}$ & $1.79 b$ & 0.14 & & \\
\hline & & $1.77 b$ & 0.13 & & \\
\hline \multirow{5}{*}{$\begin{array}{l}\text { Other Household } \\
\text { Members }\end{array}$} & & $1.74 a$ & 0.15 & \multirow{5}{*}{6.387} & \multirow{5}{*}{$p<0.001$ ** } \\
\hline & Alone & $1.81 b$ & 0.12 & & \\
\hline & With relative & $1.79 b$ & 0.17 & & \\
\hline & $\begin{array}{l}\text { With spouse and children } \\
\text { Other }\end{array}$ & $1.80 b$ & 0.13 & & \\
\hline & & $1.80 \mathrm{~b}$ & 0.10 & & \\
\hline \multirow{2}{*}{$\begin{array}{l}\text { Ownership of } \\
\text { Residence }\end{array}$} & Homeowner & 1.80 & 0.12 & \multirow{2}{*}{3.875} & \multirow{2}{*}{$\mathrm{p}<0.001 * \star$} \\
\hline & Tenant & 1.73 & 0.16 & & \\
\hline \multirow{5}{*}{ Social Security } & & $1.71 \mathrm{a}$ & 0.06 & \multirow{5}{*}{6.598} & \multirow{5}{*}{$p<0.001^{* *}$} \\
\hline & None & $1.68 a$ & 0.20 & & \\
\hline & Emekli Sandığı & $1.79 b$ & 0.13 & & \\
\hline & $\begin{array}{l}\text { Bağ-kur } \\
\text { SSK }\end{array}$ & $1.78 b$ & 0.14 & & \\
\hline & & $1.81 b$ & 0.11 & & \\
\hline
\end{tabular}

${ }^{*} p<0.05^{* *} p<0.01$; the differences between the averages containing different letters are significant. 


\section{DISCUSSION}

The elderly experience serious health problems because of physical, psychological, sexual and economic violence and neglect. However, incidents of violence and abuse are usually kept within the family. In incidents reported to the public authorities, older adults, believing that their relatives would be prosecuted, choose to remain silent as to the perpetrator, and thus accept violence (18).

An overall majority of the older adults replied "Yes" to "Do you have anyone who spends time with you, taking you shopping or to the doctor?" and "Are you helping to support someone?" and replied "No" to "Do you feel uncomfortable with anyone in your family?" "Do you feel that nobody wants you around?" and "Does anyone in your family drink a lot?"

In general, the participants reported that no one close to them had recently tried to hurt or harm them, they had enough privacy at home, and there was no one who forced them to do things they did not want to do. This could be attributed to the fact that slightly over $50 \%$ of the participants were less aged people in the 65-70 age group; therefore, they were capable of living with their spouses without being dependent on others. Özmete and Megahead reported that the highest rate of abuse was observed for "Do you have anyone who spends time with you, taking you shopping or to the doctor?" (12).

In the present study, most older adults said that they were the ones who made decisions about their lives. This result reveals that more than half of the participants retained authority over their life decisions as they were less elderly adults.

According to the descriptive statistics for the subscales (factors) of the Hwalek-Sengstock Elder Abuse Screening Test, neglect and abuse were not excessively experienced in any of the three subscales. The overall mean score for the scale was computed as $\bar{X}=1.843$. "Characteristics of the elder that make him or her vulnerable to abuse" ( $\bar{X}=1.778)$ and "Characteristics of potentially abusive situations" $(\bar{X}=1.810)$ were the subscales with the lowest and the highest mean scores, respectively. This indicates greater neglect and abuse in the "Characteristics of the elder that make him or her vulnerable to abuse" subscale in comparison with the other subscales. In the present study, the overall level of elder neglect and abuse was low, indicating elderly individuals were given due importance and were protected in the traditional family structure. In the Turkish adaptation study of the HwalekSengstock Elder Abuse Screening Test carried out by Özmete and Megahead, the overall mean score for the scale was reported as $\bar{X}=2.46$ (12). In the study conducted by Keskinoğlu et al. in the Inonu Health Center district in Izmir, Turkey, the researchers reported that the prevalence of physical and/or financial abuse among the elderly was $1.5 \%$ (11). In the study by Kalaycı et al. $57.5 \%$ of the respondents with elder relatives reported that their elder relatives were victims of violence and mistreatment perpetrated by family members or close relatives (18).

The neglect and abuse status of the participants were not significantly different with respect to gender and age $(p>0.05)$, while there were significant differences with respect to educational attainment, monthly income, number of children, other household members, ownership of residence, and social security $(p<0.05)$. The groups with increased exposure to neglect and abuse were those who had an elementary school degree or less, who had a monthly income of 1000TL and under, who were childless, who lived alone, who were tenants, who had no social security, and who had a green card. This indicates that older adults who had low educational attainment, low income, no social security, were childless, and who lived alone were more frequently victims of neglect and abuse. In the literature, there are various studies that associate increased incidence of elder abuse with low educational attainment and low 
income $(14,19,20)$. This result could be attributed to greater dependence on others and failure to adequately protect oneself because of the frequent presence of economic deprivation in older adults with low educational attainment. In their study, Özmete and Megahead stated that elder abuse was correlated with life satisfaction, use of social benefits, and satisfaction with income and age. They demonstrated that older adults younger than 75 years of age who were satisfied with their lives and incomes had a decreased risk of abuse (12). In their cohort study covering a period of 9 years, Lanch et al., identified age, race, poverty, functional disability, and cognitive impairment as risk factors for exposure to elder mistreatment (19).

In the present study, participants who lived alone reported greater exposure to neglect and abuse compared to those living with others. The higher self-reported neglect and abuse in the older adults living alone is an interesting finding that requires indepth analysis. In the present study, our researchers did not attempt to conduct an in-depth inquiry into the subject. Ergin found that living in an extended family affected psychological abuse (13).

The study results revealed increased exposure to neglect and abuse in participants who were tenants,

\section{REFERENCES}

1. Beğer $T$, Yavuzer $H$. Old age and old age epidemiology. Clinical Development 2012;3(25):1-3. (in Turkish).

2. Ministry of Family and Social Policy. The situation of the elderly in Turkey and the national action program on aging. 2013. [Internet] Available from: http:www.eyh.ov.r/upload / Node / 8638/files/blob. docx. Accessed: 15.10.2015 (in Turkish).

3. Turkish Statistical Institute. Life tables. 20132014. [Internet] Available from: http://www. tuik.gov.tr/PreHaberBultenleri.do?id=18618 Accessed:10.10.2015 (in Turkish).

4. Özmete E. The Hwalek-Sengstock elder abuse screening test: the adaptation study into Turkish. Anatolian Journal of Psychiatry 2016;17(Suppl.1):45-52. (in Turkish). who did not have social security, and those with a green card. This indicates the importance of a social security system that protects and supports senior citizens. The results of the study conducted by Ergin et al. demonstrated that the lack of social security, not being married, having physical disabilities, social exclusion, and a low level of life satisfaction affected psychological abuse (13).

In conclusion, the neglect and abuse status of participants were significantly different with respect to educational attainment, monthly income, number of children, other household members, ownership of residence, and social security $(p<0.05)$. In view of the study results, the researchers would like to make a couple of recommendations:

$\checkmark$ With the support of the media, educate the public, caregivers, and family members of older adults about old age, elder problems, elder abuse, and elder neglect.

$\checkmark$ Use the media to raise public awareness through informative and instructional efforts on elder abuse and neglect.

$\checkmark$ Conduct more comprehensive studies to identify possible risk factors through focus groups or in-depth interviews.

5. Kissal A, Beşer A. Identifying and evaluating elder abuse and neglect. TAF Prev Med Bull 2009; 8(4):35764. (in Turkish).

6. WHO. The Toronto Declaration on the global prevention of elder abuse. Geneva, World Health Organization, University of Toronto, Ryerson University, INPEA, 2002 pp 1-4.

7. Moore C, Browne C. Emerging innovations, best practices, and evidence-based practices in elder abuse and neglect: A review of recent developments in the field. Journal of Family Violence 2017;32(4):383-97.

8. Political declaration and Madrid International plan of action on ageing. United Nations, 2002. New York. [Internet] Available from: http://www.un. org/en/events/ pastevents/pdfs/Madrid_plan.pdf. Accessed:15.10.2015. 
9. Gallione C, Dal Molin A, Cristina F, Ferns H, Mattioli M, Suardi B. Screening tools for identification of elder abuse: A systematic review. Journal of Clinical Nursing 2017;26:2154-76. (PMID:28042891).

10. Ergönen AT, Can iÖ, Toprak G. Elderly abuse in women who applied to the gynecology policlinic. Journal of Forensic Psychiatry 2007;4(2):13-8. (in Turkish).

11. Keskinoğlu P, Giray H, Pıçakçıefe M, Bilgiç N, Uçku R. Physical abuse, financial abuse and neglect in elderly. Turkish Journal of Geriatrics 2004;7(2):57-61. (in Turkish).

12. Özmete Ö, Megahead HA. Screening for elder abuse among Turkish older people: Validity of the Hwalek-Sengstock elder abuse screening test $(\mathrm{H}-\mathrm{S}$ "East"). Research on Social Work Practice 2006;1-12.

13. Ergin F, Evci-Kiraz ED, Saruhan G, Benli C, Okyay P, Beser E. Prevalance and risk factors of elder abuse and neglect in a western city of Turkey: Community based study. Bulletin of the Transilvania University of Braşov, Series VI, Medical Sciences 2012;5(54):33-50.

14. Oh J, Kim HS, Martins D, Kim H. A study of elder abuse in Korea. Int J Nurs Stud 2006;43(2):203-14. (PMID:15913631).
15. Souza JA, Freitas MC, Queiroz TA. Violence against the aged: document analysis. Rev Bras Enferm 2007; 60;3:268-72. (PMID:17684902).

16. Sekaran, U. Research methods for business:A skill building approach, 4th Edition, John Wiley High Education. New York 2003, pp 270-99.

17. Hwalek M, Sengstock M. Assessing the probability of abuse of the elderly: Toward the development of a clinical screening instrument. J Appl Gerontol 1986;5:153-73.

18. Kalaycı I, Yazıcı SÖ, Şenkaynağı A. Violence perception of the old people's attendants: Sample of Suleyman Demirel University Hospital. Elderly Issues Research Journal 2015; 8(1):22-3. (In Turkish).

19. Lachs MS, Williams C, O'Brien S, Hurst L, Horwitz R. Risk factors for reported elder abuse and neglect: A nine-year observational cohort study. The Gerontologist 1997;37:469-74. (PMID:9279035).

20. Keskinoğlu P, Pıcakcıefe M, Bilgic N, Giray H,Karakus, $\mathrm{N}$, Ucku, R. Elder abuse and neglect in two different socioeconomic districts in Izmir, Turkey. International Psychogeriatrics 2007;16:1-13 (PMID:17433122). 